\title{
KÜLÖNBÖZŐ SZIGETELŐANYAGOK NEDVESSÉGFELVÉTELÉNEK VIZSGÁLATA
}

\section{INVESTIGATING THE WATER ABSORBEANCE OF DIFFERENT INSULATION MATERIALS}

\author{
Lovas Bence
}

Debreceni Egyetem Müszaki Kar: Épületgépészeti és Létesítménymérnöki Tanszék, Cím: H-4028, Magyarország, Debrecen, Ótemető utca, 2-4; Telefon / Fax: +36-52415-155, levelezési cím, bence.lovas@outlook.com

\begin{abstract}
During my work I have inspected the moisture absorbance of 6 different building insulation material in a laboratory environment. As a first step the materials were dried to a constant weight only then were they exposed to five different, equally distributed, relative humidity environments, ranging from $0 \%$ to $100 \%$. At each chosen relative humidity range the weight of the absorbed water content were measured. Then the results were analyzed. The insulations were then ranked using results from this and my previous work.
\end{abstract}

Keywords: insulation, moisture, humidity, isotherm.

\section{Összefoglalás}

Munkám során 6 különböző szigetelőanyag nedvességfelvételi tulajdonságait vizsgáltam laboratóriumi körülmények között. Tömegállandóságig történő szárítás után nedvesítőkamra alkalmazásával $0 \%$ és 100\% páratartalom között egyenletesen kiválasztott relatív páratartományban mértem az egyes anyagok nedvességfelvételét. Az eredmények kiértékelése után rangsorolással megvizsgáltam, a korábbi eredményeimet is felhasználva, melyik anyag tekinthető a mért és számított épületfizikai jellemzők alapján a legjobbnak.

Kulcsszavak: szigetelés, nedvességtartalom, páratartalom, izoterma.

\section{Nedvesség hatása a szigetelő- anyagokra}

Az építő- és szigetelőanyagok túlnyomó többsége pórusos szerkezetü. A pórusok összesített felülete rendkívül nagy lehet, aminek fontos szerepe van a nedvesség felvételében és megkötésében.

A nedvességfelvétel további vizsgálata elött fontos definiálni a következő fogalmakat:

Az adszorpció a molekulák (atomok) megkötődését jelenti a fluidum- (gáz vagy fo- lyadék) fázisból egy szilárd felületen (a felület aktív centrumain).

Az anyagok nedvességfelvevő képessége a szorpciós izotermával jellemezhető. A porózus anyagnak a környezetével való kölcsönhatása kétirányú lehet:

- ha az anyag felületén a p parciális nyomás nagyobb, mint a levegőben levő pára pg parciális nyomása, akkor deszorpció, azaz száradás történik;

- ha a felületi parciális nyomás kisebb, mint a levegőé $\left(\mathrm{p}_{\mathrm{f}}<\mathrm{p}_{\mathrm{g}}\right)$, akkor az anyag a kör- 
nyezetéből nedvességet vesz fel, szorpció indul meg. [1]

\section{Vonatkozó szabvány}

A munkám során az MSZ EN ISO 12571:2013-as szabvány iránymutatásai alapján végeztem a méréseket. Ez egy nemzetközi angol nyelvü de Magyarországon is érvényes szabvány, amely az építőanyagok és építőipari termékek szorpciós izotermájának meghatározásával foglalkozik.

A vizsgált mintadarabok melyek tömegállandóságig szárított testsürüsége 300 $\mathrm{kg} / \mathrm{m}^{3}$ alatti legalább egy $100 \mathrm{mmx} 100 \mathrm{~mm}$ felülettel kell rendelkezniük. Amennyiben egyéb forrásból bizonyítható, hogy nem befolyásolja a kísérlet végeredményeit az anyagok kisebb darabokra vághatók vagy törhetők, az egyensúlyi állapot gyorsabb elérése végett. [2]

Minden vizsgált anyagból minimum 3 mintadarab vizsgálása szükséges.

\subsection{Szorpciós izoterma meghatározá- sának módja}

A mintadarabot tömegállandóságig kell szárítani. Majd minimum 4 egymást eltérő relatív nedvességgel rendelkező tesztkörnyezetben kell nedvesíteni. A tesztkörnyezetben a választott relatív nedvességek lehetőleg egyenletesen legyenek elosztva $0 \%$ és 100 \% között. A nedvességfelvétel meghatározására a tesztkörnyezettel egyensúlyi állapotba került anyag tömegmérésével lehetséges. Az összes relatív nedvességtartalmon elvégzett mérés befejeztével felrajzolható az egyes mintadarabok szorpciós izotermája. [3-5]

\subsection{Mérésekhez használt eszközök}

- A szabvány elöírásai alapján a méréshez használható eszközök az alábbiak:

- Mérőedény, ami vízhatlan

- Mérleg, ami a mintadarabok tömegének $\pm 0,01 \%$ pontosságú mérésére alkalmas

- Az ISO 12570 szabvány elöírásainak megfelelő szárító berendezés
- Klímakamra amely a relatív nedvességtartalmat a kívánt érték \pm 5 \%-os határok között míg a hőmérsékletet \pm 2 K-es határon belül tartják

A méréseim során a mintadarabok mérete miatt mérőedényre nem volt szükség.

\section{Labormérések}

\subsection{Mintadarabok}

A mérések során az alábbi 6 anyagot vizsgáltam:

- Aerogél

- Kőzetgyapot

- Foamglas (Üveghab)

- PUR

- Formahabosított PS

- Grafitos EPS

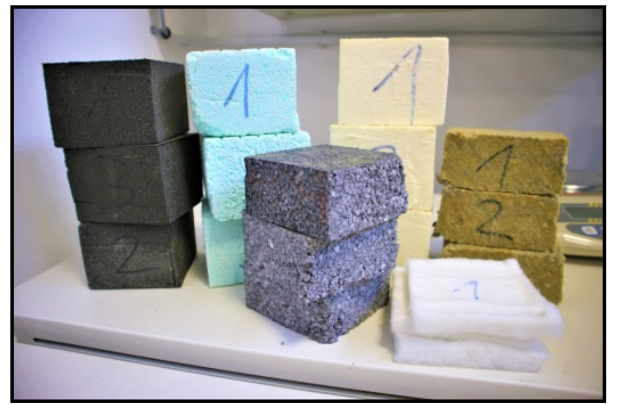

1. ábra. Vizsgált szigetelöanyag mintadarabok

Ezekből 100mm x 100mm alapú hasábokat alakítottam ki, a beszerzett szigetelöanyag lemezek vastagságától függően változó magassággal. A mintadarabokat 1-3-ig beszámoztam a pontos beazonosíthatóság érdekében.

\subsection{Mérések menete}

A mintadarabokat a Venticell 111 szárítószekrényben 24 órán keresztül szárítottam. Majd egy ezred gramm pontosságú mérleg segítségével megmértem az anyagok száraz tömegét.

Ezután a Climacell 111 nedvesítőkamra segítségével 24 órás ciklusidővel egymást 
sorban követő relatív nedvességtartalmú környezetben kondicionáltam az anyagokat. A szabvány minimum 4 vizsgálati tartományt ajánl. A szorpciós izotermák nagyobb pontosságának érdekében én 5 relatív nedvességtartománnyal dolgoztam. Ezeket a szabvány ajánlása alapján nagyjából egyenletes eloszlásban választottam meg, amelyek a következök lettek:

- $\quad 30 \%, 45 \%, 60 \%, 75 \%, 95 \%$

$\mathrm{Az}$ egyes nedvesítési fázisok végén ismét megmértem a mintadarabok tömegét.

$\mathrm{Az}$ összes relatív nedvesség tartományon, mind a száraz mind a nedves esetén mérés esetén 3 eredményt kaptam a 3 mintadarabra. Ezek alapján minden mintadarabnak külön kiszámítottam a nedvességtartalmát a szabvány által meghatározott öszszefüggés által:

$$
\omega_{A D}=\frac{m_{n}-m_{s Z}}{m_{S Z}} \times 100
$$

A szorpciós izoterma ábrázolásához meghatároztam a három minta számított nedvességtartalmak átlagát. Valamint kiszámítottam az egyes mintadarabok átlagtól való eltérését és ezeknek is vettem az átlagát.

Így a kapott adatok segítségével Microsoft Excelben jelölőkkel ellátott vonaldiagram segítségével ábrázoltam az egyes mintadarabok szorpciós izotermáit. A meghatározott relatív nedvességtartományon továbbá hibasávként feltüntettem a számított átlagtól való eltérést.

\subsection{Mérések eredményei}

A méréseim összesítéseként meghatároztam az összes anyagra vonatkozó adszorpciós izotermát és ezeket egymással összehasonlítható módon ábrázolva tüntetem fel a 2.ábrán.

Épületfizikai szempontból legjobban mindenképpen a foamglas vagy más néven az üveghab teljesített. Ez a méréseim alapján semmilyen mennyiségü nedvességet nem abszorbeált.

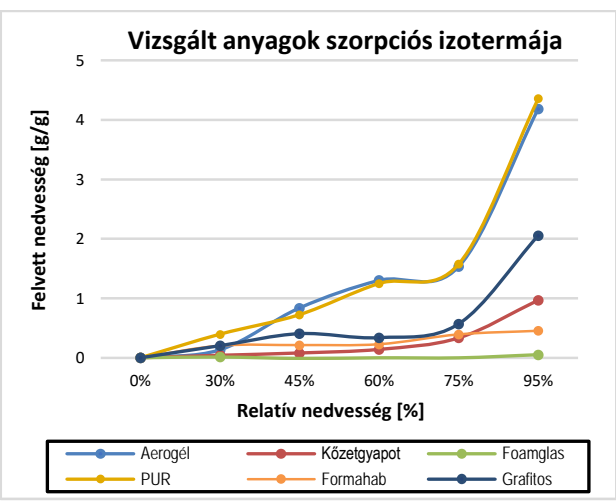

2. ábra. Eredmények összesítése

Az 2. ábrán szürke színnel jelölve látható, szinte teljesen vízszintes jelleget mutat. Egyedül a 95\%-os mérési tartományban van egy nagyon kicsi emelkedés, ami valószínüsíthetően felületi kondenzáció eredménye.

A kőzetgyapot szintén egészen jól teljesített a mérések során. Ennél az anyagnál a szálas szerkezete miatt valamelyest nagyobb nedvességfelvételt vártam a mérések előtt. A görbe jellege viszont kifejezetten kedvező tulajdonságokat mutat. 60\%-os relatív páratartalmú vizsgálatokig alacsony meredekséggel lineárisan emelkedett. 75\%nál már valamivel nagyobb mértékben. Végül elvárható módon 95\%-nál volt a legjelentösebb a felvétel, azonban még ez is igen alacsonynak mondható a többi vizsgált anyaghoz képest.

Harmadik legjobban a formahabosított polisztirol teljesített épületfizikai szempontokat figyelembe véve. Az adszorpciós izotermájának a jellege eltér ugyan a kőzetgyapotétól, de nagyságrendileg hasonló értékeket vett fel. 0-75\% relatív páratartalom esetén a kőzetgyapot izotermája felett halad, viszont a 95\%-os mérés esetén a két izoterma keresztezi egymást és a kőzetgyapot nedvességfelvétele bizonyult nagyobbnak ebben a mérési tartományban.

Negyedik legjobb szigetelőanyagként a grafitos expandált polisztirolt határoztam 
meg. Épületfizikai szempontból ennek is elönyösek a tulajdonságai, mivel 0-75\% relatív páratartalom mellett nagyságrendileg az elöző anyagokkal együtt helyezkednek el a mérés során meghatározott adszorpciós izotermájának a pontjai. A 95\%-os páratartalom esetén viszont egy nagyon nagy ugrás figyelhető meg az izotermáján. A szigetelőanyag alkalmazásánál ezt mindenképp érdemes lehet szem előtt tartani.

A vizsgálataim során az aerogél szigetelőanyag a rosszabbak közé került. Habár a hőszigetelési tulajdonságai nagyon jónak bizonyultak korábbi méréseim során, a nedvességfelvétele a mért anyagok körül az egyik legnagyobb fokú volt. 30\%-os páratartalmon viszonylag jól teljesített, viszont nagyütemü növekedést mutatott a relatív páratartalom növekedésével. 60\%-os méréstartományban már átlépte az 1 g/g \%-os értéket, amit az előző anyagok a grafit kivételével, még a 95\%-os páratartalom esetén is csak megközelítettek. Mivel az emelkedés a korai mérési tartományokban megkezdődik így sem túl előnyös épületgépészeti szempontból, mivel már alacsony páratartalom esetén is arányaiban sok nedvességet vesz fel. Emiatt kedvezőtlenül alakulhat a hővezetési tényezője és sokkal nagyobb egy esetleges szerkezeten belüli párakondenzáció kialakulása a magas nedvességtartalom miatt.

Nedvességfelvétel szempontjából a épületfizikai értelemben véve a legkedvezőtlenebb tulajdonságokkal a poliuretán szigetelőanyag teljesített. A kőzetgyapottal ellentétben itt pont kis nedvességfelvételre számítottam, mivel ez egy zártcellás szerkezetü szigetelőanyag. Az 2-es ábrán látható azonban, hogy 30\%-os relatív páratartalom esetében ennek a legmagasabb a nedvességfelvétele a mért anyagok közül.

\section{Következtetések}

A dolgozatom során mért és meghatározott szorpciós izotermák alkalmazhatóak a szigetelőanyagok páratechnikai tulajdonságainak szimulációs programokban történő pontosabb vizsgálatára mivel az ilyen szimulációk során mindig valóságot jobban közelítő eredmény kapható amennyiben az felhasznált adatok méréseken alapszanak.

\section{Szakirodalmi hivatkozások}

[1] Fekete I. (ed.): Épületfizika kézikönyv. (Handbook of Building Physics), Müszaki Könyvkiadó, Budapest, 1985, ISBN:963 10 $6428 \mathrm{X}$

[2] MSZ EN ISO 12571:2013 Építési anyagok és termékek hö- és nedvességtechnikai viselkedése. A higroszkopikus szorpciós tulajdonságok meghatározása

[3] M. Jirickova, R. Cerny, P. Rovnanikova: Measurement of Moisture Storage Parameters of Building Materials. Acta Polytechnica Vol. 43 No. 2/2002.

[4] Á. Lakatos: Investigation of water sorption properties of different insulating materials In: Ing Michal Mokryš Ing Anton Lieskovský Ph $\mathrm{D}$ (ed.) Proceedings in Advanced Research in Scientific Areas The 1st Virtual International Conference . Zilina, Slovakia, 2012.12.032012.12.07. Zilina: EDIS, 2012. pp. 18271831. (ISBN:978-80-554-0606-0) .2012.

[5] A. Lakatos: Method for the determination of sorption isotherms of materials demonstrated through soil samples. Int Rev Appl Sci Eng; 2(2): 117-121. 2011. 